\title{
Homage
}

\section{PROF. JOSÉ LEME LOPES (1904-1990): THE PIONEER OF THE MULTI-AXIAL DIAGNOSIS}

Among the various Brazilian psychiatry professors that emerged in the second half of the $20^{\text {th }}$ century, encouraging the research in the Brazilian universities, the name of professor José Leme Lopes is highlighted. He was born in Rio de Janeiro in October 1904 and died on June of 1990, in the same city. In June of 2010, at the beginning of the $21^{\text {st }}$ century, we will remember 20 years without Professor José Leme Lopes.

His most important scientific contribution was the main subject of his Thesis from 1954: "The dimensions of the psychiatric diagnosis - contribution to its systematization"1. At that time, his idea of the psychiatric diagnosis was a new multiaxial conception and granted him a fair homage and wide recognition abroad for the influence it would play in the formulation of new nosological classifications suggested by the World Health Organization and by the American Psychiatric Association. The important contribution of this Thesis was further internationally recognized when its original cover page was reproduced on the 6th edition of the Kaplan \& Sadock Comprehensive Textbook of Psychiatry ${ }^{2}$.

In 1958, Lopes became Full Professor and the Director of the Institute of Psychiatry from the Universidade Federal do Rio de Janeiro. Later he turned the Director of the Faculdade Nacional de Medicina (National School of Medicine) from 1966 to 1970. During the second period (1970-1974) under the direction of Prof. Leme Lopes that the Institute of Psychiatry was considered a national center of excellence in clinical research and began to gather candidates from Brazil and Latin America for the first Brazilian post-graduate course in psychiatry. Under his direction, the Institute of Psychiatry reached

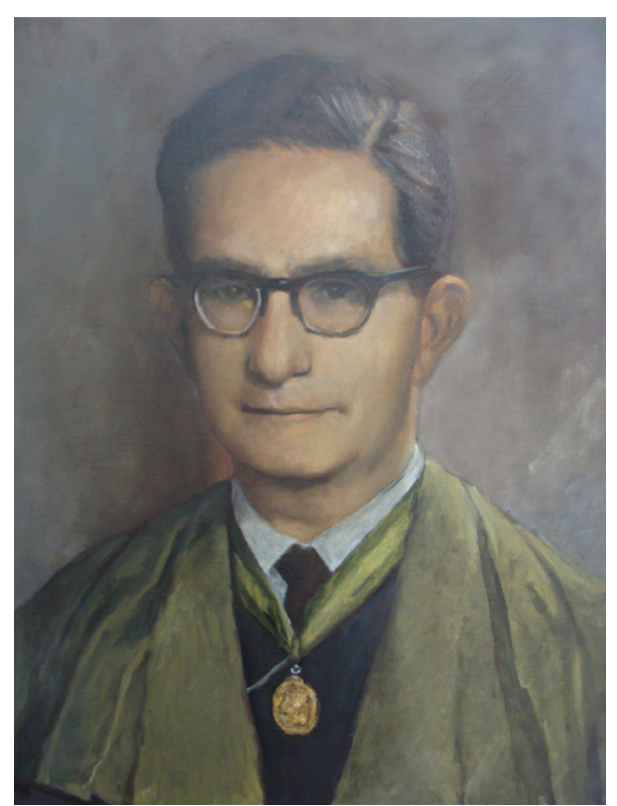

Photograph by A.E. Nardi (antonionardi@terra. com.br) from an oil painting (M. Duprat, 1998) collection of the Institute of Psychiatry, Federal University of Rio de Janeiro, Brazil. Reprinted with permission. $863 \times 1151 \mathrm{~mm}(72 \times 72 \mathrm{DPI})$

for the summit, becoming a leader in psychopathology, clinical psychiatry, and psychotherapy research in Brazil ${ }^{3}$. The institution consolidated as never before its intellectual production and its collaborators, regularly contributing to the editorial excellence of the Brazilian Journal of Psychiatry, one of the oldest Latin American publications in that field.

In 1966, Lopes was chosen to be the first president of the newly founded Brazilian Psychiatry Association. Over the years, he increased its production on historical topics, both psychopathological and philosophical, in addition to his old passion for the psychiatric diagnosis ${ }^{3}$ : "The psychiatry and the old hospice" (1965); "Pour un diagnostic en psychiatrie" (in French: 'For a diagnosis in psychiatry') (1977); "Jaspers and Heidegger" (1983); "Delusion: perspectives and treatment" (1982), among others.
Antonio Egidio Nardi Laboratory of Panic \& Respiration Institute of Psychiatry Federal University of Rio de Janeiro Rua Visconde de Pirajá 407 / 702 22410-003 Rio de Janeiro RJ - Brasil E-mail: antonionardi@terra.com.br
${ }^{1} \mathrm{MD}$, PhD, Panic \& Respiration Laboratory, Institute of Psychiatry. Federal University of Rio de Janeiro. INCT Translational Medicine (CNPq), Rio de Janeiro RJ, Brazil; ${ }^{2} \mathrm{MD}$, PhD Department of Neuroscience and Behavior, Ribeirão Preto Medical School, University of São Paulo, INCT Translational Medicine (CNPq), São Paulo SP, Brazil. 
He fought for a scientific psychiatry that was linked to medicine and to the collaboration of other aspects of human thought. At the end of his academic career, he was acclaimed by his peers with the highest academic distinction and was granted the title of Emeritus Professor of the Universidade Federal do Rio de Janeiro.

For all of these accomplishments and realizations, but principally for his visionary spirit and for the role he would play in the consolidation and modernization of psychiatry in Brazil, Prof. Leme Lopes deserves, with justice, the title of the Father of Modern Brazilian Psychiatry.

\section{REFERENCES}

1. Leme L J. As dimensões do diagnóstico psiquiátrico. Rio de Janeiro RJ, Agir, 1954.

2. Mezzich JE. International perspectives on psychiatric diagnosis. In: Sadock BJ, Kaplan HI (Eds). Comprehensive textbook of psychiatry. $6^{\text {th }}$ Ed. Baltimore: Williams \& Wilkins, 1995:692-703.

3. Bastos O. Professor José Leme Lopes: mestre exemplar. Rev Bras Psiquiatr 2001;23:36-37.

Antonio E. Nardi ${ }^{1}$

Jaime E. Hallak ${ }^{2}$

José A. Crippa ${ }^{2}$ 